\title{
The Implementation of Project Based Learning in Translation/Interpreting I Course
}

\author{
Adiwijaya, Pande Agus \\ STKIP Suar Bangli \\ adiwijayapande@gmail.com
}

\begin{abstract}
The change of paradigm of university education level in Indonesia has demanded changes in its curriculum. More skill-based curriculum is demanded as the result of global competition. As the paradigm change, the teaching method is should be changed as well. Translation/Interpreting I course in English Education Department of STKIP Suar Bangli has been changed to be more skill-based course as before it was emphasized on theory only. This course was taught by using Project Based Learning approach in order to give more practices to the students rather than teaching theories. This approach was conducted in 1 semester consisting of 16 meetings. It was done in fifth semester students of English Education Department of STKIP Suar Bangli. It was qualitative descriptive study which aiming at describing how was the implementation of Problem Based Learning in this course. Some instruments were utilized such as documentation, observation sheet, questionnaire and evaluation rubric. The data were analysed quantitatively and qualitatively. Based on the finding it was found that the students were having probem in the beginning of this implementation but finally they realized that this approach is much more helping them in learning translation/interpreting I.
\end{abstract}

Keywords: project based learning, translation/interpreting course I.

\section{Introduction}

Nowadays, education in Indonesia is demanding the students should acquire certain skills. This condition is caused by the high competition in local, national and global level. Whoever acquire more skills would win the competition. Therefore, Indonesia as one of the nation competing in this world demanding its people to acquire certain skills whenever they graduated from any education level. It caused the government of Indonesia demanding more skills-based curriculum on the education system.

This situation also applies in university level in Indonesian. Although university education is actually mainly emphasizing on theory mastery but seemed that this paradigm is slowly changing as the expectation of today's era demand. Therefore, many universities are changing their curriculum not to be merely emphasizing on theory but need to insert some beneficial and market-demand skills. Therefore, the curriculum of universities is not only focused in theory but also should insert some skills that should be acquired. In the end, it is expected that universities in Indonesia will produce more productive and skillful outcome who comprehend the theory of their field.

In order to answer the challenge, English Education Department of STKIP Suar Bangli did the revision of curriculum and embrace the new paradigm of university level education in Indonesia. Some of the courses were changed, removed, replaced and just reclassified. One of the changes is re-classifying the courses. There were two classifications of the courses, namely content-based course and skill-based course. The content-based course is designed to make the students comprehend the content of the course. Therefore, the course is emphasizing on the students' comprehension on certain issue or knowledge. Meanwhile skillbased course is designed to make the students acquire certain skill in the end of the course. Therefore, the course emphasizes on students' skill mastery rather than comprehending the theory.

As one of the skill-based course, translation/interpreting I is not only teaching theory, but also skill of translating and interpreting, so the content and practices in the teaching 
learning process should focus in developing students' skill in translating and interpreting. This course is also one of the re-classified courses in English Education Department of STKIP Suar Bangli. Therefore, the teaching method that had been implemented previously in this course cannot be implemented again. Previously, this course had been taught through lecturing and presenting some theories and less of practicing the translation and interpreting.

Project-based learning is intended to give the students a chance to practice their skill in translating and interpreting. Most of the meetings were planned to practice students' skill in translation and interpreting. It is in line with the syllabus of Translation/Interpreting I course which classify this course as a skill-based course not a content-based course. Through the project based learning, the students were having some projects of translating documents and interpreting real life presentation.

One of the methods that is seemingly to be success is Project-based Learning. This approach has been reported successful through the research review about Project-Based Learning by Thomas (2000). He summarized that this approach has been successful in America from 1995-1997 as the report New American Development Corp. Overall, ELOB publications report that nine of ten schools that implemented Expeditionary Learning in 1993 demonstrated significant improvement in students' test scores on standardized tests of academic achievement.

Empirically, the success of Project-based Learning has been reported by Dharma (2016) through his research about Project-based Learning in STKIP Suar Bangli in Broadcasting Course. His research revealed that the implementation of Project-based Learning gave new learning atmosphere for the students. The students could feel and aware the significance of their learning. The active enggangement of the students during making the project had changed the learning paradigm from passive learning into active learning. It can not be denied that it made the students to get something new outside of the book they have or explanation from their lecturer.

$\mathrm{He}$ also said that the use of PBL was re-emerging as a teaching approach as universities strive to incorporate experiential learning into a broader range of university programs. Evidently, the experience of the introduction of PBL to an Broadcasting course at STKIP SUAR Bangli has resulting in many positive outcomes for students; however, there remain to be challenges that we have to address to make it a successful teaching approach.

Based on this point of view, it was very important to conduct Project-based Learning in Translation/Interpreting I Course since the students are intended to have real-life experiences of translating and interpreting English into Indonesian. Therefore, the students would acquire both skills and knowledge of translation and interpreting as the demand of today's era.

\section{Research Methods}

This is a case study aiming to describe the implementation of project based learning in Translation/Interpreting I Course in English Education Department of STKIP Suar Bangli in academic year 2016/2017. This research utilized descriptive qualitative method to prove deep and detail information on how to implement Project Based Learning, students' achievement, students' perception and challenges in implementing this method in Translation/Interpreting I Course.

Subjects of this research were the students of semester V of English Education Department of STKIP Suar Bangli. There were 8 students in total consisting of 3 males and 5 females. Object of this study was the description of the implementation of Project-Based Learning Approach in Translation/Interpreting I course.

This research was conducted within 1 semester consisting of 16 meetings. The meeting planning can be seen in the following Table 1 . 
Table 1. Teaching planning

\begin{tabular}{|c|c|c|}
\hline \multicolumn{3}{|c|}{ Course: Translation/Interpreting I } \\
\hline Meeting & Material & Description \\
\hline 1 & Introduction & $\begin{array}{l}\text { Course contract, evaluation, do's and don'ts, } \\
\text { course requirement }\end{array}$ \\
\hline 2 & $\begin{array}{l}\text { Definition of translation \& interpreting, } \\
\text { obstacles in translation, technique of } \\
\text { translation, translation/interpreting } \\
\text { profession }\end{array}$ & Lecturer presentation \& class discussion \\
\hline 3 & Descriptive text translation (Eng-Indo) & Students' presentation \\
\hline 4 & Recount text translation (Eng-Indo) & Students' presentation \\
\hline 5 & Narrative text translation (Eng-Indo) & Students' presentation \\
\hline 6 & Procedure text translation (Eng-Indo) & Students' presentation \\
\hline 7 & News Item text translation (Eng-Indo) & Students' presentation \\
\hline 8 & Mid Term Assignment & Submission of Text Translation (Eng-Indo) \\
\hline 9 & Interpreting education issue & $\begin{array}{l}\text { Students' presentation of interpreting } \\
\text { someone's discourse }\end{array}$ \\
\hline 10 & Interpreting cultural issue & $\begin{array}{l}\text { Students' presentation of interpreting } \\
\text { someone's discourse }\end{array}$ \\
\hline 11 & Interpreting economic issue & $\begin{array}{l}\text { Students' presentation of interpreting } \\
\text { someone's discourse }\end{array}$ \\
\hline 12 & Interpreting political issue & $\begin{array}{l}\text { Students' presentation of interpreting } \\
\text { someone's discourse }\end{array}$ \\
\hline 13 & Interpreting local issue & $\begin{array}{l}\text { Students' presentation of interpreting } \\
\text { someone's discourse }\end{array}$ \\
\hline 14 & Book Translation & $\begin{array}{l}\text { Class discussion of translating a book, } \\
\text { obstacle in translation, necessity of translating } \\
\text { book, method of book translation. }\end{array}$ \\
\hline 15 & Book Translation & $\begin{array}{l}\text { Class discussion of translating a book, } \\
\text { obstacle in translation, necessity of translating } \\
\text { book, method of book translation. }\end{array}$ \\
\hline 16 & Final Project & $\begin{array}{l}\text { Submission of Book Translation (Eng- } \\
\text { Indo/Indo-Eng). Project-Based Assignment. }\end{array}$ \\
\hline
\end{tabular}

The researcher used four instruments in this research, namely documentation, observation sheet, questionnaire and evaluation rubric. Documentation were utilized in order to know how the Project Based Learning was carried out. Observation sheet was used to get information about challenges in implementing this approach. Questionnaires were used to get information on students' perception. Evaluation rubric was used to find information on students' achievement in Translation/Interpreting I Course.

\section{Finding}

\section{Finding and Discussion}

\section{The Implementation of Project-based Learning in Translation/Interpreting I Course}

The translation/interpreting I course was conducted in 16 meetings which were divided into 14 class meeting, 1 meeting for Mid-term test and 1 meeting for Final test. It is in line with the policy of the university.

Translation/interpreting I course was designed as skill-based course. It means that output of this course is acquiring certain skill rather than comprehending certain theory. Therefore, the learning activities were directed to acquire skill of translating and interpreting English into Indonesian. Although it is skill-based course, some theories related to translation and interpreting were discussed as well. 
As the description of this course, translation/interpreting $\mathrm{I}$ is intended to give the students experiences of translating formal and non-formal text as well as interpreting English discourse into Indonesian. Theories of translating and interpreting are also delivered to the students. However, the activities are emphasized on students' performance on translating and interpreting English into Indonesia. The evaluation is emphasized on performance and project based assessment. The learning objective was at the end of the course, students are expected to be able to attempt a good translation and interpreting from English into Bahasa Indonesia at the level of discourse semantics and lexico-grammar, in the forms of sentences, clauses, phrases, words and morphemes, in the stories and information genres.

The implementation of Project-based Learning in Translation/Interpreting I Course was adapting the steps proposed by Stix and Hrbek (2017). This adaptation was conducted since there was no standardized steps of implementing Project-based Learning. The different step is highly possibly because every project is unique and need its own strategy and rules to accomplish. The following is the steps of the Project-based Learning in this course:

1) Showing real-life samples

In this step the lecturer gave the example of project that the students should produce. In the first mid-term assignment the students should accomplish individual genrebased document translation and for the final project the students worked in group to accomplish academic book translation. The translation was from English to Indonesian.

2) Presenting role of project

In this step, the lecturer provided the steps of how to accomplish the project. Terms and conditions regarding to the project accomplishment. Discussion were conducted in this step so it was expected that there would be no misunderstanding between the lecturer and the students.

3) Negotiating the criteria for evaluating the project

Criteria of evaluation was discussed to the students as the basis for conducting their project. The discussion was a part of being an active learning. It was intended to give an opportunity for them to be responsible for their own learning. They were expected to be more responsible because the evaluation criteria were democratically decided and they had taken part to decide it. This activity was definitely new for the students since previous experiences were not involving them to decide the evaluation criteria. Usually, the only did the test and did not take part on the evaluation criteria.

4) Discussing the genre and book that would be translated

This step was conducted independently by the students to determine what kind of genre-based document that they would take in the first term and what book they would translate for the final project. This step was not conducted in the classroom. The students took their own time and place to accomplish this step.

5) Preparing the necessary material

In this step, the students were looking for the text and book that would be translated. The text and book should be suitable with the criteria established by the lecturer. Before they translated the text and book, they should consult and had permission from the lecturer.

6) Creating the project

Here, the students were doing the translation. In this process, the students were welcome to consult with the lecturer for any obstacles faced along the process.

7) Preparing project presentation

The preparation of presenting their project was done both individually and in group. For the mid-term project, the students were preparing the presentation individually 
and for the final project, the students were preparing in group. The presentations were conducted in class.

8) Presenting the project

The presentation was evaluated as well in order to know whether the translation was original or not. It was done to avoid plagiarism and machine-used translation in which they translated by using automatic translation tools as two cases happened in the translation presentation exercises.

9) Project evaluation

There were two kinds of evaluation for the project. First evaluation was conducted by the lecturer by using the negotiating criteria. This score was used as the score to be an input for their final score. Second evaluation was from the students themselves as the reflection to create the project. This evaluation is important because they could have reflection to improve their capacity in the process of translating text or book.

\section{Students' Achievement in Translation/Interpreting I Course}

Students' achievement was evaluated by using evaluation rubric. It is because the objective of this course is performing translation and interpreting from English into Indonesian. There were some evaluations conducted in this course such as performance evaluation and project evaluation. The performance evaluation covered translation presentation and interpreting presentation while project evaluation covered Mid-term project and final project. Besides that, students' attendance was also considered for their final score. The following is the percentage of determining the final score:

Table 2. Percentage of determining final score

\begin{tabular}{lc}
\hline \multicolumn{1}{c}{ Score } & Percentage \\
\hline Attendance & $15 \%$ \\
\hline Assignments (Translation and Interpreting Performance) & $20 \%$ \\
\hline Mid-term project & $30 \%$ \\
\hline Final Project & $35 \%$ \\
\hline
\end{tabular}

Based on this percentage, the formula of students' final score is as follows:

Description:

$$
F S=\frac{((15 * S 1)+(20 * S 2)+(30 * S 3)+(35 * S 4))}{100}
$$

FS : Students' final score

S1 : Score of students' attendance

S2 : Score of assignments

S3 : Score of mid-term project

S4 : Score of final project

Then, the final score was converted into letter score in order to decide the Students' Achievement Index within the third semester. The conversion used the following criteria:

Table 3. Student's score conversion

\begin{tabular}{cccc}
\hline Interval Score in Number & Score in Letter & Value & Category \\
\hline $80-100$ & $\mathrm{~A}$ & 4 & Very good \\
\hline $65-79$ & $\mathrm{~B}$ & 3 & Good \\
\hline $55-64$ & $\mathrm{C}$ & 2 & Sufficient \\
\hline $40-54$ & $\mathrm{D}$ & 1 & Poor \\
\hline $10-39$ & $\mathrm{E}$ & 0 & Very Poor \\
\hline
\end{tabular}


Table 4.

Based on this percentage, the final score of the students can be seen in the following

Table 4. Students' final score

\begin{tabular}{ccccc}
\hline No & $\begin{array}{c}\text { Students' } \\
\text { Registration } \\
\text { Number }\end{array}$ & Name & \multicolumn{2}{c}{ Final Score } \\
\cline { 3 - 5 } & \multirow{2}{*}{2015103001} & Student 1 & 81 & $\mathrm{~A}$ \\
\hline 2 & 2015103002 & Student 2 & 79 & $\mathrm{~B}$ \\
\hline 3 & 2015103003 & Student 3 & 80 & $\mathrm{~A}$ \\
\hline 4 & 2015103004 & Student 4 & 82 & $\mathrm{~A}$ \\
\hline 5 & 2015103006 & Student 5 & 82 & $\mathrm{~A}$ \\
\hline 6 & $2016103012 \mathrm{P}$ & Student 6 & 68 & $\mathrm{~B}$ \\
\hline 7 & $2016103011 \mathrm{P}$ & Student 7 & 75 & $\mathrm{~B}$ \\
\hline 8 & $2016103013 \mathrm{P}$ & Student 8 & 75 & $\mathrm{~B}$ \\
\hline & & & &
\end{tabular}

From the result of the evaluation it can be seen that all of the student passed the course with good result in which 4 students got "very good" score and 4 other students got "good" score. It indicated that the students were able to finish translation/interpreting I course well by the implementation of project-based learning.

\section{Students' Perception on the Implementation of Project-based Learning in Translation/Interpreting I Course}

Students' perception was gathered by using questionnaires distributed to the students consisting of 5 items. Those items were adopted from Dharma (2016) asking about: a) The existence of Project-based Learning itself during their study, b) their feeling in doing project, c) Something which they learn from Project-based Learning, d) The way of lecturer presents the instructions and materials, and e) The students' belief on Project-based Learning.

Result of the questionnaires showed that all of the students admitted that they had Project-based Learning for the first time in their study. They were not familiar with the Project-based Learning. They thought that university teaching program is always about lecturing. They go to campus, sit down and listen to the lecturer. Their paradigm was also supported by the implementation of teaching method used by the lecturer in previous semester. They only got lecturing and in the mid-term and final meeting, they got paperbased test. Therefore, the implementation of Project-based Learning changed students' paradigm about the teaching learning process in university level.

Result of questionnaires also revealed that the students were confused with the implementation of Project-based Learning. They did not know what to do when they got problem during finishing the project. This situation made them stressed in the process but in the end of the project, they were happy and proud since they never thought before they could do the project well. It means that the Project-based Learning not only helping the students to acquire translation and interpreting skill but also encourage the students to learn more.

Based on the questionnaires given, the students mentioned that they got new experience of how to learn something. The teaching method was new for them and it was interesting to be engaged though they were confused in the beginning. The activity of accomplishing their project was hard but challenging. It made them to manage themselves better and they realized that they were not only learning translation and interpreting but also learning soft skills at once. Time management, task-management, and emotion management were some soft skills that they learn through Project-based Learning. 
Regarding to the lecturer's presentation about the material and instruction, most of the students mentioned that they need clearer explanation especially about the instruction of the project. In presenting the material, which was about theory of translation and interpreting, they said it was clear enough. Therefore, in the next implementation, the lecturer should provide as clear as possible instruction of the project to the students. It may avoid students' confusion toward the project accomplishment.

From the questionnaires asking about students' belief, it was found that the Projectbased Learning should be implemented more frequent. The students thought that their capacity in term of theory and practices much more developing rather than only studying about translation and interpreting through lecturing. They thought that it might help them and other students in different levels or courses to acquire more knowledge and skills than using lecturing method in the class.

\section{Discussion}

Based on the observation conducted in the class it was found some difficulties as consideration in implementing PBL in Translation/Interpreting I Course. The students were not familiar with Project-based learning so all of them were confusing in finishing the project. They were afraid of consulting their difficulties with the lecturer. The thought that consulting to the lecturer is forbidden and can be considered as cheating. Therefore, there were many misunderstanding of accomplishing the project.

Using automatic translator tools became the obstacles in improving their skill in translating the document. It was an irony since the idea of using these tools are to help them in finding some unidentified words. However, they just type the source language (English) and then translating the sentences by using these tools. This practice was damaging the process since they could not practice their own skill to translate.

In interpreting practices, the students were having much problem in interpreting their friend's presentation since the did not make sufficient preparation. Moreover, most of the students were interpreting in rush so many parts of the presentation were missing.

In translation practices, the other students did not give many contributions to their friends. Many of them, even did not understand with the translation. They seemed afraid of giving their opinion to their friend. They felt it might make their friend angry. This feeling was not good in class discussion since there were no many students' contribution to the material presented by their friend.

Instruction of the project was not well-comprehended by the students. It made the students stressed and they made many mistakes along the project accomplishment process. This not-well-comprehension could emerge as the consequence of unclear instruction from the lecturer and misunderstanding from the students.

Based on those challenges, some suggestions are proposed in order to make the implementation be better in the following academic year. The students should be engaged with more practices of project-based learning. It can be done by implementing this approach in other courses before the get translation/interpreting I course. Therefore, the lecturer of translation/interpreting I course should make any discussion with other lecturers who are teaching in other courses which are given before translation/interpreting I course. By frequent engagement of the students with project-based learning approach, so the will be familiar and learn earlier before they are having translation/interpreting I course.

The use of automatic translator tools is actually helping the students to do the project. However, some limitation should be provided. The students are allowed to use this tool whenever they had difficulty in finding the word meaning or only translating a single word. If they translate sentence or even text by using the tool, so they will not learn actually. Since they only typing not translating the document. Moreover, many aspects of translation were 
violated such as the context of the text, dictions, and meaning transfer.

The difficulty faced by the students in interpreting was caused by inexistence of interpreting example. The lecturer did not provide sufficient example for the students of how to do interpreting. The example can be direct interpreting conducted by the lecturer or other person or from video. This example can be a reference for the students to do interpreting in their practices. Some discussion should also be done before entering the practices.

In conducting the translation presentation many students did not contribute as expected by the lecturer. Many of them were in silent. Therefore, the lecturer should provide a system of translation presentation which may provide all of the students to contribute. The lecturer can provide all of the students an evaluation rubric. This rubric should be fulfilled whenever their friend presents the result of their translation. So then, all of the students will contribute to the translation of their friends and the presenter will have many inputs for their translation.

In order to avoid the not-well-comprehension in the class. The lecturer should make sure the instruction is easy to understand and to do. Moreover, the explanation of the instruction should consider the level and experience of the students. It is in line with Botha (2010) who identified the introduction of the project at the beginning of the semester and frequent reminders up until its commencement, as a key success factor of Project-based learning implementation. Another effective strategy was to use edited videos from student project de-briefs in former years to help inform new cohorts of students about the project, and to provide "warnings and encouragement" (Thomas \& Meehan, 2006: 132).

\section{Conclusion}

Based on the discussion, it was found that Project Based Learning beneficial for students' learning in translation/interpreting I course. They had new experiences of learning which was only taught by lecturing only. Through this approach the students were having more practices and self-management experience in accomplishing the project. This approach was successful in improving students' achievement which can be seen from their final score. However, Project-based Learning was still having some challenges that should be considered in the implementation.

Based on the conclusion, some suggestions might be derived as follows:

1) The Project Based Learning was found to be more effective on the skill-based course rather than lecturing. It means that Project Based learning should be referred by other lecturers who are teaching skill-based courses to be implemented.

2) The implementation of Project Based Learning should be preceded by wellpreparation because it will influence the whole process of the course.

3) The curriculum in English Education Department of STKIP Suar Bangli should be more emphasizing on skill-based approach as the challenge of global competition.

4) More other research should be done in order to get more comprehensive pint of view about the implementation of Project Based Learning. It can be done at the same level or other level of education in Indonesia.

\section{References}

Dharma, I Putu Suyoga. (2016). Implementing Project Based Learning Approach in Broadcasting Course. Jurnal Wahana Chitta-STKIP Suar Bangli. pp. 48-57.

Botha, M. (2010). A project-based learning approach as a method of teaching entrepreneurship to a large group of undergraduate students in South Africa. Education as Change, 14 (2). pp 213-232. 
Meehan, B. \& Thomas, I. (2006). A Project-Based Model for Professional Environmental Experience. Applied Environmental Education \& Communication, 5 (2). pp 127-135.

Stix, Andi \& Hrbek, Frank. (2017). Chapter 11. The Nine Steps of Project-Based Learning. Retrieved from:

http://www.ascd.org/publications/books/106031/chapters/The_Nine_Steps_of_Project -Based_Learning.aspx

Thomas, John W. (2000). A Review of Research on Project-Based Learning. California: The Autodesk Foundation. Available at

http://www.bie.org/research/study/review_of_project_based_learning_2000 